\title{
EDIBLE COATING PATI SINGKONG (Manihot utilissima Pohl) TERHADAP MUTU NENAS TEROLAH MINIMAL SELAMA PENYIMPANAN
}

\section{Edible coating of cassava starch (Manihot utilissima Pohl) on quality of pineapple minimally processed during storage}

\author{
Satria Wati Pade* \\ Program Studi Teknologi Hasil Pertanian, Politeknik Gorontalo, Kabupaten Bone Bolango, Gorontalo, Indonesia \\ Doi: 10.37195/jac.v1i1.59
}

*KORESPONDENSI

Telepon: +62-852-4088-2266

E-mail: indonk@poligon.ac.id

\section{JEJAK PENGIRIMAN}

Diterima: 15 Nov 2018

Revisi Akhir: 10 Des 2018

Disetujui: 12 Jan 2019

\section{KATA KUNCI}

Lapisan edible, Nenas, Pati Singkong (Edible coating, Pineapple, Cassava starch)

\begin{abstract}
Pineapple is desirable to be consumed fresh, but it taking too long in stripping the pineapple's outer skin. Therefore, currently, the technology of processing horticultural products is minimally applied. Minimum fruit processing can speed up product shelf life. One way to overcome this is coating. Hydrocolloid edible coating is one type of coating with starch as the base material found in several types of tubers, one of which is cassava tuber. This study used a completely randomized design method consisting of one control sample and 3 treatments, cassava starch concentrations were repeated three times, namely A1: 3\% cassava starch, A2: $4 \%$ cassava starch, A3: 5\% cassava starch with 8 days observation. The variables observed were vitamin $C$, weight loss and color. The results showed that the highest vitamin $C$ content was in the treatment of $5 \%$ cassava starch at $3.20 \mathrm{mg}^{100 \mathrm{~g}^{-1}}$ and the lowest was the control treatment of $3.15 \mathrm{mg} .100 \mathrm{~g}^{-1}$. The smallest weight loss was A3 treatment of $73.75 \%$ and the biggest was control treatment $79.67 \%$. The average value of the highest color was found in A3 treatment, which was around $66.92^{\circ}$ showed yellow-red.
\end{abstract}

\section{PENDAHULUAN}

Dalam menghadapi era ekonomi global dan perdagangan bebas, produk hortikultura terutama buah-buahan akan menghadapi persaingan yang ketat. Buah-buahan yang bermutu tinggi dengan volume yang cukup dan tersedia secara kontinyu merupakan kunci dalam persaingan tersebut. Nenas mempunyai kontribusi sebesar $8 \%$ dari produksi buah segar dunia. Indonesia menempati urutan ketiga terbesar setelah Tahilanda dan Philipina sebagai Negara penghasil nenas dan olahannya (Hadiati \& Indriyani, 2008).

Nenas menjadi prioritas tanaman yang dikembangkan di Indonesia karena memiliki potensi ekspor, terutama bagi industri pengolahan buah. Produksi nenas Indonesia cukup besar. Berdasarkan Angka Tetap (ATAP) tahun 2015 produksi nenas mencapai 1,73 juta ton. Hampir seluruh wilayah Indonesia merupakan daerah penghasil nenas karena didukung oleh iklim tropis yang sesuai (Kementerian Pertanian, 2016).

Nenas biasanya dikonsumsi dalam bentuk segar ataupun diolah menjadi jus namun proses pengupasan kulit luarnya memerlukan waktu yang cukup lama dikarenakan teksturnya yang kasar dan keras. Oleh sebab itu, sekarang ini telah diterapkan teknologi pengolahan produk-produk hortikultura secara minimal atau dikenal dengan istilah minimally process. Penggunaan buah-buahan hasil pengolahan minimal menjadi tren penelitian pada saat ini, walaupun pengolahan minimal akan mempercepat umur simpan produk. 
Edible coating merupakan suatu metode yang dapat memperpanjang umur simpan dan mempertahankan mutu buah segar pada suhu ruang. Keluarnya gas, uap air dapat dicegah dengan penggunaan edible coating sehingga proses pematangan buah dan browning dapat dihambat. Edible coating yang berupa lapisan pada permukaan kulit buah tidak akan berbahaya jika ikut dikonsumsi dengan buah. Pelapis atau coating berfungsi sebagai penghalang terjadinya penguapan air dari dalam buah sehingga kualitas mutu dapat dipertahankan dan ramah lingkungan (Hwa, Natalia, Happy, \& Isnain, 2009). Terdapat tiga jenis bahan komponen utama edible coating yaitu hidrokoloid, lipida dan komposit. Jenis yang paling umum digunakan adalah hidrokoloid.

Kelebihan edibel coating yang dibuat dari bahan hidrokoloid seperti pati merupakan bahan pelapis alami, tidak beracun dan aman bagi kesehatan adalah pati singkong sehingga edible coating berbasis pati layak untuk dikembangkan. Butir pati apabila dipanaskan akan membentuk larutan koloid yang kental.

Salah satu pati yang dihasilkan dari umbiumbian di Indonesia adalah singkong. Berdasarkan data BPS Provinsi Gorontalo (2017), produksi ubi kayu pada tahun 2015 mencapai 21.801.415 ton.

Ubi kayu memiliki beberapa keunggulan, diantaranya adalah kadar gizi makro (kecuali protein) dan mikro tinggi, kadar glikemik dalam darah rendah, kadar serat pangan larut tinggi, dalam usus dan lambung berpotensi menjadi prebiotik dan merupakan sumber kalori potensial di wilayah yang didominasi oleh iklim kering (Widowati \& Wargiono, 2009).

Pengolahan minimal pada buah nenas masih jarang dilakukan karena kandungan kadar air nenas yang relatif tinggi dan tekstur buah yang agak lunak. Oleh karena itu, penelitian penggunaan edible coating berbahan dasar pati singkong terhadap kualitas nenas terolah minimal selama penyimpanan dipandang perlu dilakukan.

\section{BAHAN DAN METODE}

\section{Bahan}

Pati singkong 3\%, 4\% dan 5\% berasal dari bahan baku lokal Gorontalo, gliserol 5\% diproduksi oleh merk KGaA Darmstadt,
Germany, Iod 0,01 N diproduksi oleh merk KGaA Darmstadt, Germany, asam sitrat diproduksi oleh PT. Golden Sinar Sakti, Jakarta, Indonesia dan nenas varietas Mas dari daerah Kotamobagu.

\section{Ekstraksi Pati Singkong (Dewi, 2014) yang Dimodifikasi}

Umbi singkong dikupas lalu dibersihkan umbinya. Umbi diparut untuk mendapatkan bubur umbi, kemudian bubur umbi yang didapat ditambah dengan air 3:1. Bubur umbi diperas untuk memisahkan ampas cairan dan pati. Cairan pati yang didapat diendapkan 3-5 jam. Limbah cair hasil pengendapan dibuang, bubur pati yang didapat dijemur sampai kering, kemudian digiling dan diayak.

\section{Pembuatan Larutan Edible Coating (Usni, Karo-Karo, \& Yusraini, 2016) yang Dimodifikasi}

Edible dibuat dari pati singkong dengan penambahan plasticizer berupa gliserol. Pati singkong dilarutkan dalam aquades $100 \mathrm{ml}$, kemudian dipanaskan hingga mencapai suhu $60{ }^{\circ} \mathrm{C}$. Setelah itu, plasticizer berupa gliserol ditambahkan sampai homogen. Konsentrasi gliserol yang digunakan merujuk pada penelitian yang telah dilakukan, yaitu $5 \%(\mathrm{v} / \mathrm{v})$. Setelah tercampur, larutan dipanaskan selama kurang lebih 5 menit. Kemudian dinginkan hingga mencapai suhu ruang.

\section{Aplikasi Edible Coating (Usni dkk., 2016) yang Dimodifikasi}

Buah nenas dikupas dan dibersihkan matanya, lalu diiris tipis. Irisan nenas diblanching pada suhu panas $70^{\circ} \mathrm{C}$ selama 5 detik. Selanjutnya nenas direndam dalam 150 ppm asam sitrat selama 30 detik untuk mencegah terjadinya reaksi pencoklatan. Setelah itu, dicelupkan ke dalam larutan edible coating yang dibuat dari pati singkong dan ditambah gliserol sebesar $5 \%$ yang dipanaskan pada suhu $70{ }^{\circ} \mathrm{C}$. Nenas kemudian diangkat dan diangin-anginkan sampai kering, lalu disimpan dalam suhu refrigerator $10{ }^{\circ} \mathrm{C}$. Dilakukan pengamatan perubahan selama 8 hari.

\section{Metode Analisis}

Analisis Kadar Air. Kadar air dianalisa menggunakan metode oven. 
Vitamin C. Kandungan vitamin C ditentukan berdasarkan titrasi iodin. Pengujian kadar vitamin $C$ menggunakan 20 gram bahan yang telah dihancurkan menggunakan blender sampai diperoleh slurry. Sebanyak 10 gram dimasukkan kedalam labu takar $100 \mathrm{ml}$ dengan penambahan aquades sampai tanda tera. Bahan selanjutnya disaring untuk memperoleh filtrat. Filtrat diambil sebanyak $5 \mathrm{ml}$ dengan pipet dan dimasukkan kedalam Erlenmeyer $125 \mathrm{ml}$, lalu ditambahkan $2 \mathrm{ml}$ indikator amilum 1\% dan aquades $20 \mathrm{ml}$. Larutan tersebut dititrasi dengan iod 0,01 N sampai terjadi perubahan warna (biru keunguan). Perhitungan vitamin $C$ dengan standarisasi larutan iodin yaitu pada setiap 1 $\mathrm{ml}$ 0,01 $\mathrm{N}$ iodin ekuivalen dengan $0,88 \mathrm{mg}$ vitamin $C$. Rumus vitamin $C$, yaitu:

Vit.C $\left(\mathrm{mg} .100 \mathrm{~g} \mathrm{bahan}^{-1}\right)=\frac{\mathrm{ml} \mathrm{Iod} \times 0,08}{\text { Berat sampel (gram) }} \times 100$

Susut Bobot. Perhitungan susut bobot dilakukan berdasarkan persentase penurunan berat bahan sejak awal hingga akhir penyimpanan. Digunakan persamaan sebagai berikut:

\% Susut Bobot $=\frac{\text { Bobot awal }- \text { Bobot akhir }}{\text { Bobot awal }} \times 100$

Tabel 1. Nilai ohue dan daerah kisaran warna kromatis (Hutchings, 1999)

\begin{tabular}{ll}
\hline Nilai hue & Daerah kisaran warna \\
\hline $342^{\circ}-18^{\circ}$ & Merah-ungu \\
$18^{\circ}-54^{\circ}$ & Merah \\
$54^{\circ}-90^{\circ}$ & Kuning merah \\
$90^{\circ}-126^{\circ}$ & Kuning \\
$126^{\circ}-162^{\circ}$ & Kuning - hijau \\
$162^{\circ}-198^{\circ}$ & Hijau \\
$198^{\circ}-234^{\circ}$ & Biru- hijau \\
$234^{\circ}-270^{\circ}$ & Biru \\
$270^{\circ}-306^{\circ}$ & Biru- ungu \\
$306^{\circ}-342^{\circ}$ & Ungu \\
\hline
\end{tabular}

Nilai a dan $\mathrm{b}$ digunakan untuk menentukan derajat HUE (Table 1). Derajat HUE berfungsi untuk menentukan warna dari produk. Dengan menggunakan rumus derajat ${ }^{\circ} \mathrm{Hue}$ sebagai berikut:

$$
\mathrm{H}=\tan =\frac{\mathrm{b}}{\mathrm{a}}
$$

Warna. Pengujian warna dilakukan dengan menggunakan Portable Colorimeter AMT-507. Sampel yang akan diukur warnanya diletakkan dalam wadah kemudian diukur dengan Portable Colorimeter dan akan menghasilkan nilai yang akan didapatkan dan dikonversikan ke dalam bentuk nilai L, a, b. Nilai L adalah kecerahan, nilai a adalah cahaya pantul yang menghasilkan warna kromatik campuran merah hijau, nilai b adalah warna kromatik biru dan kuning.

\section{Desain Penelitian}

Jenis penelitian yang dilakukan merupakan penelitian eksperimental menggunakan Rancangan Acak Lengkap (RAL) yang terdiri dari 1 kontrol dan 3 perlakuan konsentrasi pati singkong yang diulang sebanyak tiga kali, yaitu:

A1: pati singkong $3 \%$ : gliserol $5 \%$

A2: pati singkong $4 \%$ : gliserol $5 \%$

A3: pati singkong $5 \%$ : gliserol $5 \%$

Masing-masing perlakuan diamati perubahannya selama delapan hari penyimpanan.

\section{HASIL DAN PEMBAHASAN \\ Vitamin C}

Pengamatan vitamin $C$ dalam penelitian ini dilakukan setiap selang 2 hari. Gbr. 1 menunjukkan persentase vitamin $C$ yang terjadi pada nenas terolah minimal pada penyimpanan hari ke-0 sampai hari ke-8.

Gbr. 1 menunjukkan nilai rata-rata kandungan vitamin $C$ berkisar antara 2,473,19 mg.100 g $\mathrm{g}^{-1}$. Pada penyimpanan sampai dengan hari ke-8, kandungan vitamin $C$ tertinggi diperolah pada perlakuan A3 sebesar 2,73 mg.100 $\mathrm{g}^{-1}$ dan yang terendah pada perlakuan control (tanpa coating) sebesar 2,40 mg.100 g $\mathrm{g}^{-1}$. Hal ini disebabkan karena adanya bahan pelindung edible coating yang diaplikasikan kepada daging nenas.

Semakin tinggi konsentrasi pati maka vitamin $C$ nenas meningkat. Peningkatan kadar vitamin $C$ terjadi karena nenas yang dilapisi dengan pelapis yang lebih tebal lebih sedikit kehilangan air sehingga akan mempertahankan kadar vitamin C buah. Menurut Baldwin (2002) "penguapan air buah atau sayur dapat dicegah dengan pelapis edibel. Pelapisan buah dengan polisakarida akan mengurangi kontak dengan oksigen sehingga menghambat terjadinya oksidasi asam askorbat". 
Menurut Winarno (2008) "L-dehidroaskorbat merupakan hasil oksidasi dari asam askorbat yang memiliki sifat labil dan bisa mengalami perubahan lebih lanjut menjadi L-diketogulonat yang tidak memiliki keaktifan vitamin C".

Hasil analisis ragam menunjukkan bahwa perlakuan dan lama penyimpanan tidak berpengaruh nyata terhadap kandungan vitamin $C$. Penurunan kandungan vitamin $C$ dapat dipengaruhi oleh proses respirasi dan transpirasi yang menyebabkan menurunnya kadar air nenas. Analisa sidik ragam dapat diketahui bahwa nilai $\mathrm{F}$ hitung dari lama penyimpanan yaitu hari pertama 0,02, hari kedua 0,72 hari keempat 2,19, hari keenam 0,64 dan hari kedelapan 0,48 lebih kecil dari $\mathrm{F}$ tabel $(0,05)$ yaitu 5,14 yang menunjukan bahwa perlakuan konsentrasi pati singkong tidak berpengaruh pada hasil vitamin $C$ yang sehingga tidak dilakukan uji lanjut BNT.

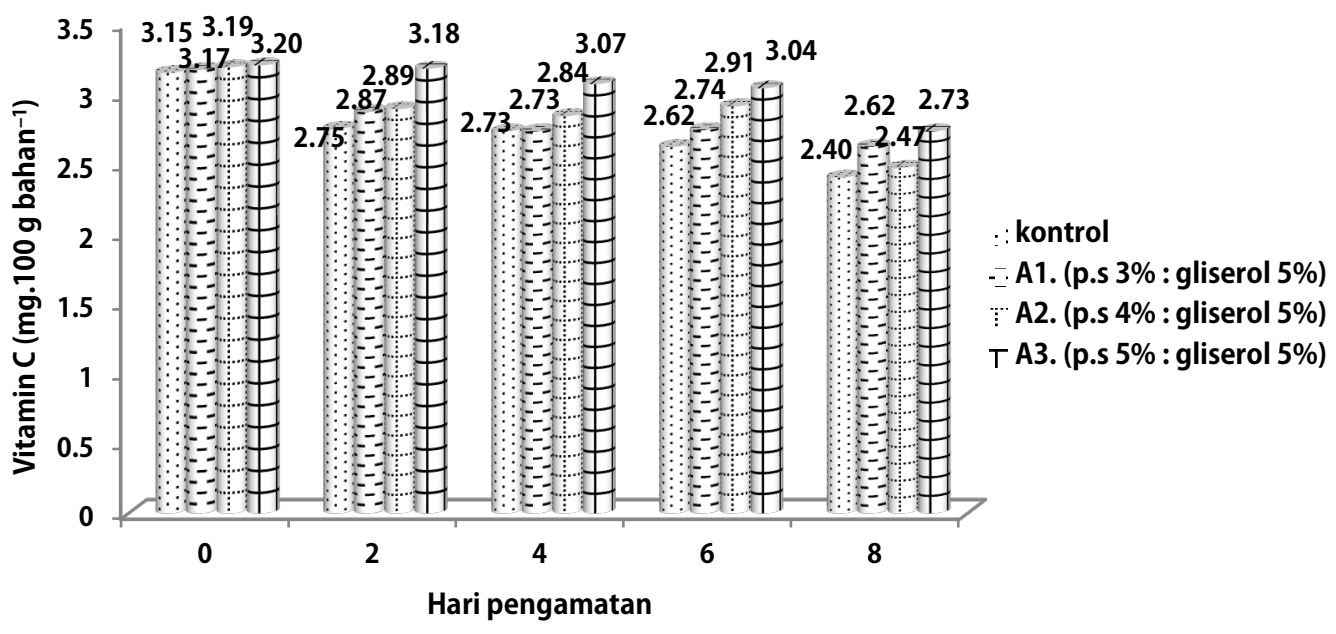

Gbr. 1. Kandungan vitamin $\mathrm{C}$ nenas terolah minimal selama penyimpanan

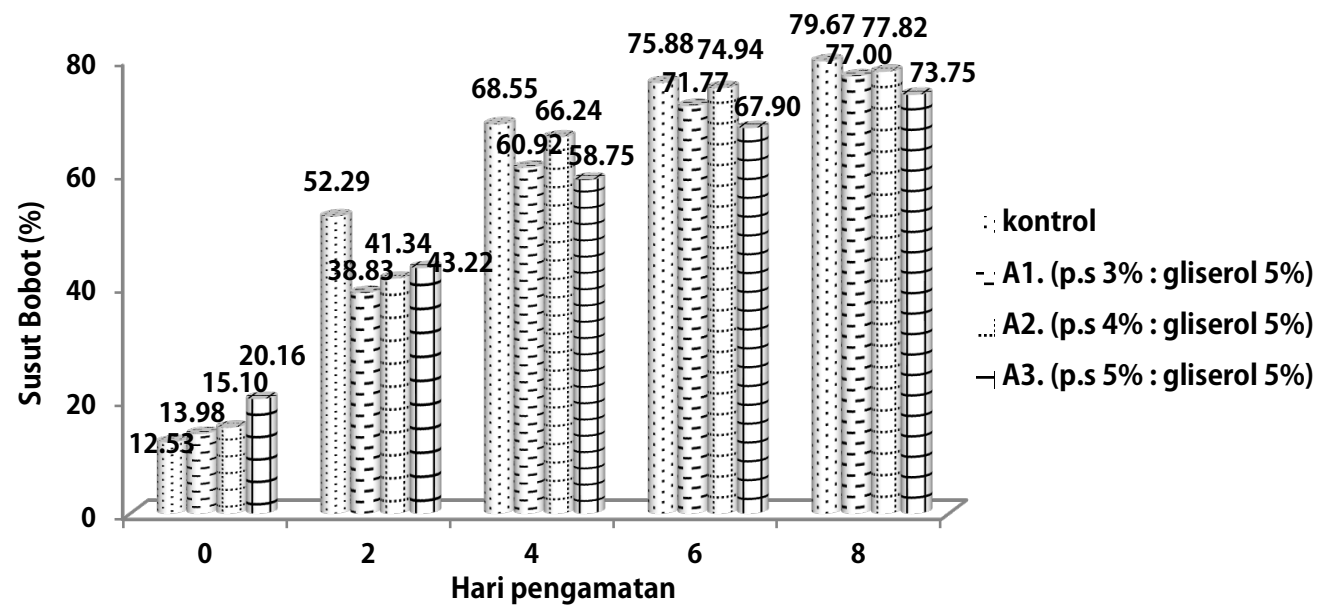

Gbr. 2. Susut bobot nenas terolah minimal selama penyimpanan

\section{Susut Bobot}

Gbr. 2 menunjukkan persentase susut bobot yang terjadi pada nenas terolah minimal pada penyimpanan hari ke-0 sampai hari ke-8. Dilihat dari Gbr. 2 persen susut bobot buah nenas terolah minimal semakin meningkat pada setiap harinya. Hari ke-2 sampai hari ke delapan penyimpanan susut bobot buah nenas tanpa coating terlihat mengalami peningkatan drastis. Sampai pada penyimpanan hari ke-8, susut bobot tertinggi terdapat pada nenas terolah minimal tanpa coating yaitu $79,67 \%$ pada hari kedelapan dan terendah terdapat pada perlakuan A3 yaitu $73,75 \%$. Pada perlakuan A1, A2 dan A3 penyusutan bobot terjadi lebih lambat, hal ini disebabkan karena adanya coating pati singkong yang menghambat terjadinya proses kehilangan penguapan kadar air dari dalam bahan. Hasil penelitian ini sejalan dengan penelitian 
(Alsuhendra, Ridawati, \& Santoso, 2011) yang menyebutkan bahwa "susut pada buah selama penyimpanan relatif kecil apabila diaplikasikan edible coating, karena edible coating mampu mencegah kehilangan air dari dalam buah". Edible coating merupakan barrier yang baik terhadap air dan oksigen. Selain itu juga dapat mengendalikan laju respirasi buah, oleh sebab itu banyak digunakan untuk mengemas produk buah-buahan segar dan produk pangan lainnya, seperti produk konfeksionari, daging dan ayam beku, sosis, produk hasil laut dan pangan semi basah.

Penggunaan substrat oleh mikroba untuk perkembangannya yang menyebabkan rusaknya struktur sel serta adanya proses fisiologis berupa respirasi dan transpirasi menjadi penyebab terjadinya susut bobot pada buah (Winarno, 1997).

Berdasarkan hasil analisa sidik ragam dapat diketahui bahwa nilai $\mathrm{F}$ hitung dari lama penyimpanan yaitu hari kedua 1,15, hari keempat 4,71, hari keenam 4,49 dan hari kedelapan 2,40 lebih kecil dari $\mathrm{F}$ tabel $(0,05)$ yaitu 5,14 dan F tabel $(10,92)$ hasil analisa sidik ragam ini menunjukan bahwa perlakuan dan penyimpanan tidak berpengaruh pada hasil susut bobot yang dihasilkan sehingga tidak perlu dilakukan uji lanjut BNT. Hal ini disebabkan karena perbedaan konsentrasi pati singkong antar perlakuan kecil sehingga tidak memberikan pengaruh nyata terhadap susut bobot nenas terolah minimal.

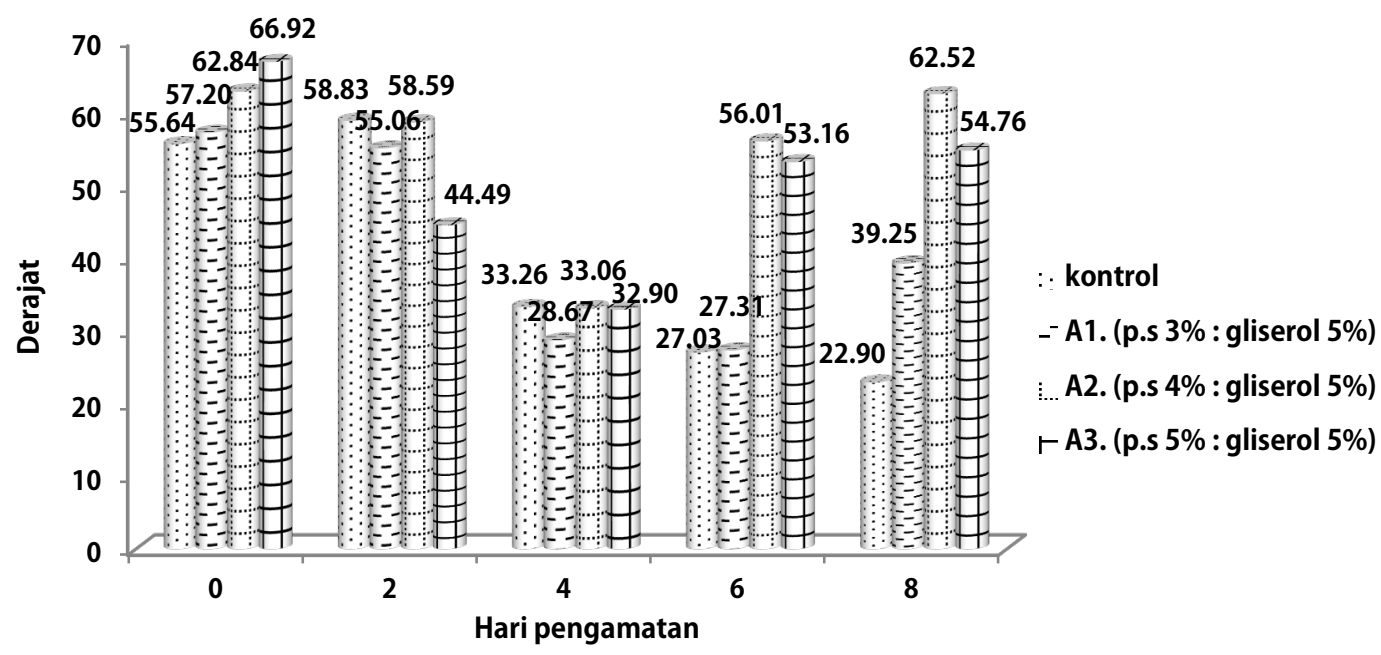

Gbr. 3. Derajat warna nenas terolah minimal selama penyimpanan

\section{Warna}

Dari Gbr. 3 uji warna dengan menggunakan derajat HUE, dapat dilihat bahwa warna buah nenas pada kontrol menurun pada hari keempat sampai hari kedelapan. Nilai rata-rata dari warna buah nenas yang tertinggi terdapat pada perlakuan A3 hari pertama dengan aplikasi edible coating yaitu berkisar $66,92^{\circ}$ dilihat dari standar nilai Hue yaitu $54^{\circ}-90^{\circ}$ yaitu kuning merah. Warna kuning merah diidentikkan dengan karotenoid. Karotenoid merupakan senyawa stabil dan tetap ada dalam jaringan. Karotenoid tersembunyi karena adanya klorofil. Nilai terendah derajat warna terdapat pada kontrol hari kedelapan yaitu $22,90^{\circ}$ tanpa aplikasi edible coating, dilihat dari standar nilai Hue berkisar antara $18^{\circ}-54^{\circ}$ yaitu warna merah. Proses perubahan warna yang terjadi selama proses penyimpanan disebabkan terjadinya perombakan pigmen pada jaringan buah seiring terjadinya proses respirasi (Usni dkk., 2016).

\section{KESIMPULAN}

Dari hasi penelitian dapat disimpulkan bahwa Perlakuan terbaik secara kimiawi terdapat pada perlakuan A3 yaitu pati singkong 5\% dengan kandungan vitamin $C$ 3,20 mg.100 g ${ }^{-1}$, susut bobot terjadi lebih lambat yaitu $73,74 \%$ sampai pada hari kedelapan, dan warna $66,53^{\circ}$. Berdasarkan hasil penelitian diperoleh kemasan edible coating mampu mempertahankan mutu nenas 
terolah minimal selama 6 hari pada suhu penyimpanan $10^{\circ} \mathrm{C}$.

\section{PENGHARGAAN}

Ucapan terima kasih kepada pihak kampus Politek Gorontalo yang telah meminjamkan sarana dan prasarana yang mendukung proses penelitian serta pihak-pihak yang telah dengan ikhlas turut membantu.

\section{DAFTAR PUSTAKA}

Alsuhendra, Ridawati, \& Santoso, A. I. (2011). Pengaruh penggunaan edible coating terhadap susut bobot, $\mathrm{pH}$ dan karakteristik organolpetik buah potong pada penyajian hidangan dessert. Prosiding Seminar Nasional FMIPA-UT.

Baldwin, E. A. (2002). Coatings and other supplemental treatments to maintain vegetable quality. In J. A. Bartz \& J. K. Brecht (Ed.), Postharvest Physiology and Pathology of Vegetables (2nd ed., pp. 418440). Boca Raton: CRC Press.

BPS Provinsi Gorontalo. (2017). Luas panen, produksi, dan produktivitas tanaman pangan provinsi gorontalo. Retrieved July 10, 2018, from https://gorontalo.bps.go.id/dynamict able/2018/01/24/396/luas-panenproduksi-dan-produktivitas-tanamanpangan-provinsi-gorontalo-2017.html.

Kementerian Pertanian. (2016). Outlook: komoditas pertanian sub sektor hortikultura. Retrieved July 23, 2018, from http://epublikasi.setjen.pertanian.go.id/ep ublikasi/outlook/2016/Hortikultura/OUTL OOK\%20NENAS\%202016/files/assets/co mmon/downloads/OUTLOOK\%20NENAS \%202016.pdf.

Dewi, A. K. (2014). Pengaruh penambahan bahan pengawet alami dalam pembuatan edible coating berbasis pati singkong (Manihot utilissima Pohl) terhadap kualitas pasca panen cabai merah (Capsicum annum L.). (Skripsi, Universitas Islam Negeri Maulana Malik Ibrahim, Malang).

Hadiati, S., \& Indriyani, N. L. P. (2008). Petunjuk Teknis Budidaya Nenas. Animal Genetics (Vol. 39). Solok-Sumatera Barat: Balai Penelitian Tanamn Buah Tropika.

Hutchings, J. B. (1999). Food Color and Appearance. Second edition. Maryland: Chapman Hall Food Sc.

Hwa, L., Natalia, S., Happy, C., \& Isnain, N. (2009). Pengaruh Edible Coating Terhadap Berat Apel Potongan. Prosiding Seminar Nasional Teknik Kimia Indonesia.

Usni, A., Karo-Karo, T., \& Yusraini, E. (2016). Pengaruh edible coting berbasis pati kulit ubi kayu terhadap kualitas dan umur simpan buah jambu biji merah pada suhu kamar, Jurnal Rekayasa Pangan dan Pertanian 4(3), 293-303.

Widowati, S., \& J. Wargiono (2009). Nilai Gizi dan Sifat Fungsional Ubi Kayu. Dalam J. Wargiono \& S. Hermanto (Ed.), Ubikayu: Inovasi Teknologi dan Kebijakan Pengembangan (hlm. 320-346). Bogor: Puslitbang Tanaman Pangan.

Winarno, F. G. (1997). Kimia Pangan dan Gizi. Jakarta: Gramedia Pustaka Utama.

Winarno, F. G. (2008). Kimia Pangan dan Gizi. Bogor: M-Brio Press. 